\title{
From the Windrush Generation to the 'Air Jamaica generation': Local authority support for families with no recourse to public funds
}

\section{Introduction}

Over the past year, immigration has been a continued focus of policy debates in the global north, with governments in Hungary and Italy elected on openly anti-immigration and 'welfare chauvinist' platforms. On the other side of the Atlantic the US federal government family separations policy has also been a source of fierce dispute. In the UK, the potential implications of Brexit for EU migrants in the UK and the treatment of the children of the 'Windrush Generation' under the hostile (or 'compliant') environment has caused particular controversy and the precipitated the resignation of the Home Secretary.

However, there has been less discussion of the rights of the next generation of migrants who came to the UK from the Commonwealth after the Immigration Act 1971. Often from the same Caribbean countries as the Windrush Generation (Price and Spencer, 2015; Jolly, 2018), they could be described as the 'Air Jamaica generation' after the former national carrier's regular flights from Kingston's Norman Manley Airport to London Heathrow between 1974 and 2007. In contrast to those migrating to the UK in the immediate post war period, families in the post-Windrush era came not as British passport holders but were 'subject to immigration control', with no recourse to public funds (NRPF) and the risk of becoming undocumented if they overstayed the length of their visa.

As the children of the 'Air Jamaica generation' have NRPF and restrictions on the right to take up paid employment, they don't have access to the welfare state or social security system that children with British citizenship have. They therefore run an increased risk of destitution, defined in section 95 of the Immigration and Asylum Act 1999 as lacking adequate accommodation (or any means of obtaining it), or not being able to meet other essential living needs. This has serious consequences for child welfare. There have been three serious case reviews into child deaths in England reported in the past year involving children with NRPF, all of which referred to their NRPF status as an exacerbating factor (NSPCC, 2018).

One of the few state welfare entitlements for families with NRPF is support from local authority children's services under section 17 of the Children Act 1989. Section 17 was intended to give local authorities the power to provide 'a range and level of services' for children who were in need because of disability or if 'a reasonable standard of health or development' would not be achieved without the local authority providing a service. It was not intended as a replacement for social security benefits or homelessness assistance. However, section 17 does give provision for: "providing accommodation and giving assistance in kind or in cash." In the absence of any other means of welfare support, families with NRPF who present to children's services can be given subsistence support and accommodation under section 17, often on a long-term basis. This has subsequently resulted in the emergence of an improvised and contingent branch of social work aiming to provide financial and housing support to families that have become destitute as a result of the NRPF rule. Unlike other fields of social work practice, this parallel system of support for destitute 
migrant families exists without statutory guidance from central government under Section 7 of the Local Authority Social Services Act 1970. Additionally, unlike other areas of social care, local authorities do not receive an allocation from Westminster for the costs of supporting families with NRPF, resulting in services that are under resourced and separate from mainstream welfare support.

\section{Context}

Child migrant destitution and the provision of section 17 support to mitigate its effects take place against the backdrop of renewed concern about the social welfare implications of austerity, and the re-emergence of extreme poverty in the UK. This is exemplified by the UN Special Rapporteur on extreme poverty and human rights' criticisms of the effect of austerity on poverty in the UK (OHCHR, 2018) and by the growth of foodbanks and increasing food insecurity since 2010 (Lambie-Mumford, H. \& Dowler, E., 2014; Loopstra et al. 2015; Dowler and Lambie-Mumford, 2015; Garthwaite, 2016).

Narratives of deservingness in relation to welfare, and the removal of welfare entitlements as a punishment for actions which do not comply with standards or expectations of behaviour have become a familiar feature of the welfare state in recent years. An emphasis which can be traced back to the new Labour emphasis on rebalancing 'rights and responsibilities (Dwyer, 2004), and which was extended through the coalition government's introduction of Universal Credit, with its system of sanctions and fines (Dwyer and Wright, 2014; Reeve, 2017).

Welfare chauvinism based on immigration status has often evolved in parallel with welfare conditionality based on social class (Guentner et al, 2016), but it is immigration welfare chauvinism which has been the most pervasive form of welfare conditionality in the UK, having developed incrementally under Labour and Conservative governments alike since the 1970's, and predating other forms of welfare conditionality. However, for Taylor-Gooby (2016) migrant exclusions from the welfare state form part of a wider programme of reducing the amount of national resources which are spent on recipients of social security spending, including changes to taxation and reductions in working age benefits, and which contributes to exacerbating and embedding social divisions. Nonetheless, for migrants welfare conditionality has usually taken a distinctive form, with the almost complete removal of rights to work for asylum seekers and undocumented migrants contrasting sharply with the wider policy of labour market activation where social security is conditional on entering the labour market or making efforts to become more employable (Dwyer, 2004).

The issue of access to social security benefits has informed debates across Europe on 'welfare tourism' particularly in the years immediately before and after EU enlargement to include the A2 and A8 states (Shutes, 2017). More recently, the impact of immigration on public services featured prominently in the leave campaign during the Brexit referendum (Gietel-Basten, 2016), with a correlation between negative attitudes towards immigration and EU enlargement and voting for Brexit (Arnorssona and Zoegabc, 2018), and higher support for leaving the EU in areas that had experienced higher immigration in the period leading up to the vote (Goodwin and Milazzo, 2017).

\section{Statutory neglect}

I have previously suggested the concept of statutory neglect as a way of framing the form of welfare conditionality experienced by migrant children who are excluded by statute from the welfare safety net of social security and homelessness assistance (Jolly, 2018). Statutory neglect is not a result of 
poor practice on the part of individual local authorities or social workers, but rather is a structural form of neglect as a result of welfare chauvinist policy and/or legislation which does not have regard for the health and wellbeing of particular types of children.

Most definitions of child neglect take an individual, rather than a structural or collective perspective, and focus on the actions by parents or legal guardians (HM Government, 2015; US Department of Health and Human Services, 2010). However, ideas of what constitutes neglect evolve over time and in different contexts (Corby, Shemmings, \& Wilkins, 2012), and Erikson and Egeland (2002) recognise that a failure to provide support so parents can meet their children's needs can be a form of neglect, while Sethi et al. (2013) take an ecological perspective on neglect which includes structural factors such as law and policy. The concept of statutory neglect draws on these acknowledgments of the broader societal factors that contribute to neglectful situations, by including situations where neglect is a direct result of law or policy.

Statutory neglect occurs when children have experiences as a result of law or policy that would meet the definition of neglect if as a result of action by a parent or carer. It could include lack of food, clothing and shelter; physical or emotional harm or danger; or emotional needs (HM Government 2010, p. 38). As such, it differs from the legal concept of wilful neglect in the Criminal Justice and Courts Act 2015, where a person is treated neglectfully in the care of a medical professional in a hospital, care home or domiciliary care service. Statutory neglect is structural, only occurring when the structures and policies themselves, rather than an individual substandard care worker or care service, neglect the needs of children.

This chapter uses the concept of statutory neglect as a lens to critically examine subsistence support given to children and families with NRPF by local authorities in England under section 17 of the Children Act 1989. The focus is on English local authorities because child welfare legislation differs in the other three nations of the UK. In Wales the relevant legislation is Section 37 of the Social Services and Well-being (Wales) Act 2014. In Scotland, support is provided under Section 22 of the Children (Scotland) Act 1995 and in Northern Ireland, Article 18 of the Children (Northern Ireland) Order 1995 is the relevant legislation. Nonetheless, although child welfare law differs across the UK, immigration control is a reserved matter to the UK government, and consequently the NRPF rule applies across the UK. Therefore, there are examples from across the four nations of the UK of how the NRPF rule impacts at a local authority level, such as Farmer's account of social work with families with NRPF in Glasgow (Farmer, 2017); Mackenzie and Stephen's (2015) research into how NRPF status affects those experiencing gender based violence in Wales; and, finally, research for the Belfast Area Domestic and Sexual Violence and Abuse Partnership on domestic abuse and women with NRPF (Dudley, 2014). Mindful of the danger of methodological nationalism (Wimmer and Schiller, 2002), the intent here is not to reduce analysis to the boundaries of the nation state, as processes of statutory neglect can be observed in other contexts beyond the borders of the UK, such as the Trump administration's 'Zero Tolerance' protocol which separated the children of undocumented migrants from their parents after crossing into the US. However, it is useful to study processes within the boundaries of a nation state, as the specifics of how laws and policies are constructed and interact with the lives of those who are subject to them is particular to the national context. 


\section{Methods}

Freedom of information requests were made to all thirty-three London Borough Councils in recognition of the fact that a majority of families supported under section 17 are likely to be in London (Price and Spencer, 2015). In addition, in order to provide a regional comparison with experiences outside the capital, a second set of freedom of information requests were made to nine English local authorities. This sample was chosen to include one local authority from each of the English regions. Local Authorities with the largest number of non-British residents according to the 2011 census were chosen from each region. The sample was not intended to be representative of the whole population of families with NRPF, but was geographically representative of the local authorities in each region that were likely to have the largest number of children with NRPF. Local authorities were asked to provide: the number of children and families who were supported under section 17 in October 2018; the numbers of referrals received in the previous financial year; and the weekly subsistence rates paid to families with NRPF. Freedom of information requests were supplemented by information in the public domain from Local Safeguarding Children's Board and local authority websites.

\section{Findings}

\section{Numbers supported}

The lowest number of families with NRPF supported by a Local Authority was eight, and the highest was 156, with a mean number of families being supported across all local authorities being 41 . Three out of the five local authorities with the highest numbers of families were in London. However, despite the likely high proportion of families with NRPF who live in London, the authority that was supporting the largest numbers of families was Birmingham City Council, and there were families with NRPF supported by local authorities in all the English regions. This suggests that the issue of families with NRPF becoming destitute is not an issue solely confined to London and the South East of England.

\section{Refusal of section 17 support}

Most of the local authorities did not record the number of referrals received for families with NRPF or the number of refusals of support. It is therefore difficult to track what happens to families who present as destitute to local authorities but are refused section 17 support. This in itself is a child welfare concern because, without a means to other welfare support, and without the legal entitlement to paid employment in many cases, families with NRPF are left at risk of various forms of labour or sexual exploitation (Pinter, 2011). However, twelve Local Authorities did disclose the numbers of families that were referred (or self-referred) for section 17 support. From this it is possible to work out how many referrals resulted in section 17 support being provided. Three local authorities supported all of the families who were referred to them between April 2017 and March 2018. However, the majority had some form of pre-assessment screening for immigration status and eligibility, which resulted in families with NRPF being refused financial assistance or housing. In half of the local authorities, fewer than half of the total number of referrals resulted in a family being given section 17 support. It is not possible to know the reasons for refusal as in many cases this was not recorded, but five local authorities did record when support was refused due to immigration status. These amounted to 347 families across five local authorities, all in London, ranging from six 
percent of all referrals to 67 percent. As screening for immigration status takes place before an assessment of need (NRPF Network, 2018), it is not known whether these families would otherwise have been assessed as destitute and provided with section 17 support. Nonetheless, it is indicative of what Humphries (2004) describes as the 'unacceptable role for social work' in implementing immigration control, and of the various ways in which immigration control can conflict with, or even take precedence over child welfare (Barn and Kirton, 2014).

The proportion of referrals which resulted in a service being provided under section 17 varied widely. The mean number of refusals across the local authorities was 40 percent, but this conceals a broad range - from the two authorities who supported all of those who were referred, to at the other extreme, one authority who refused 80 percent of those who were referred to them. Of the five local authorities who received the highest number of referrals, three were also in the top five with the highest number of refusals.

\section{Supported out of Borough}

22 local authorities disclosed the numbers of families that were provided with accommodation under section 17 of the Children Act outside of the local authority area, for local authorities outside of London this was typically a small minority of the total, although Newcastle was unusual in that the majority of families were given housing outside the city. London boroughs were far more likely to support families out of area, in outer London six out of thirteen boroughs supported a majority of families out of area, and five out of the six inner London Boroughs who responded housed a majority of families with NRPF outside of the borough, and Westminster supported all of the families outside the area.

There may be individual welfare reasons for families to be housed outside the area, such as to protect them from the risk of trafficking or exploitation (Department for Education, 2018a), and one authority housed a number of families outside of the area at the request of the family. However, it does have the effect of moving families away from support networks and has been identified in a serious case review as a risk factor in the death by starvation of Lynne Mutumba who was supported with her mother out of area by Croydon Borough Council (Smith, 2018). It is also notable that the practice of housing families out of area, while common for families with NRPF, is now increasingly also used for families that are not subject to immigration control. Under powers introduced in 2012, local authorities can discharge their duty to homeless families by offering them a year's tenancy in the private sector, a power which has been extensively used to move families outside London and into cheaper accommodation in the West Midlands and other areas of the South East (The Independent, 2015). This practice resonates with Guentner et al's (2016) observation that restrictions on welfare in the UK have historically been trialled on migrants before being extended to other groups who are perceived as 'underserving'.

\section{Support Given}

In the absence of guidance from central government under section 7 of the Local Authority Social Services Act 1970 on subsistence support rates, support levels varied widely. Of the 38 local authorities where information was available, just over half published guidance for social workers about the rates of support given to families. London boroughs were far more likely to have NRPF policies which included subsistence rates than other authorities. Only three out of the eight representative authorities of the English regions had subsistence policies, but eighteen of the 33 
London boroughs had published policies. The range of subsistence support rates for a family with one parent and two children varied from $£ 65$ per week to $£ 225.14$ per week. The mean weekly payment across all 21 local authorities with published policies was $f 120.29$.

Seven Local Authorities didn't specify rates of support, but based them on an individual assessment of needs, as required by the Working Together to Safeguard Children guidance (Department for Education, 2018). However, without any guidelines as to how subsistence should be assessed and calculated, it is difficult to know how consistent and equitable they were in practice. Some authorities offered guidance about the criteria that should be used by social workers when deciding rates of support during assessments. Merton varied the rate they paid to families: "depending if food [was] included and water rates [and] other income received from charity and family network". Redbridge also varied their rate according to family circumstance: "some families have no other support, whereas some do have other support, for example from friends, church, or benefits that other family members are claiming for them." In contrast, Waltham Forest calculated the amount by estimating a budget which included "cost for food for the entire family; cleaning materials, essential products for babies and young children-nappies and formula milk (plus additional payments on a case by case basis)."

Table 1: Weekly rates for one parent and two children

\begin{tabular}{|c|c|c|c|}
\hline \multicolumn{2}{|l|}{ Local Authority } & \multirow{2}{*}{$\begin{array}{l}\text { Weekly } \\
\text { amount* for a } \\
\text { family of one } \\
\text { parent and two } \\
\text { children. } \\
\end{array}$} & \multirow{2}{*}{$\begin{array}{l}\text { Notes } \\
\text { Based on assessment of needs }\end{array}$} \\
\hline Inner London & Camden & & \\
\hline & Hackney & - & No published policy \\
\hline & Hammersmith and Fulham & f111.90 & \\
\hline & Haringey & _- & No published policy \\
\hline & Islington & £134 & \\
\hline & Kensington and Chelsea & $£ 225.14$ & Benefit rate \\
\hline & Lambeth & £106.17 & section 4 \\
\hline & Lewisham & £105 & \\
\hline & Newham & f106.17 & section 4 \\
\hline & Southwark & - & No published policy \\
\hline & Tower Hamlets & $£ 77.50$ & \\
\hline & Wandsworth & - & No published policy \\
\hline & Westminster & $£ 202.63$ & $90 \%$ benefit rate \\
\hline \multirow[t]{7}{*}{ Outer London } & Barking and Dagenham & $f 105.22$ & $\begin{array}{l}\text { Between } £ 70.78 \text { and } £ 176 \\
\text { depending on size of family }\end{array}$ \\
\hline & Barnet & _- & No published policy \\
\hline & Bexley & 102.56 & \\
\hline & Brent & f149.86 & In line with S4/S95 rates \\
\hline & Bromley & - & Based on assessment of needs \\
\hline & Croydon & $£ 110.78$ & \\
\hline & Ealing & f158.98 & \\
\hline
\end{tabular}




\begin{tabular}{|c|c|c|c|}
\hline & Enfield & - & No published policy \\
\hline & Greenwich & f105.78 & \\
\hline & Harrow & f110.85 & \\
\hline & Havering & f114.98 & \\
\hline & Hillingdon & $f 135$ & \\
\hline & Hounslow & - & No published policy \\
\hline & Kingston upon Thames & - & No published policy \\
\hline & Merton & - & Based on assessment of needs \\
\hline & Redbridge & - & Based on assessment of needs \\
\hline & Richmond upon Thames & - & No published policy \\
\hline & Sutton & $f 65$ & \\
\hline & Waltham Forest & _- & Based on assessment of needs \\
\hline \multirow[t]{8}{*}{ Regional Local Authorities } & Leicester & - & No published policy \\
\hline & Luton & - & Based on assessment of needs \\
\hline & Manchester & _. & Based on assessment of needs \\
\hline & Southampton & _ & No published policy \\
\hline & Bristol & _ & No published policy \\
\hline & Birmingham & f105.30 & $\begin{array}{l}\text { Policy currently under review, } \\
\text { but rates reviewed on a case by } \\
\text { case basis at discretion of team } \\
\text { manager }\end{array}$ \\
\hline & Leeds & f113.25 & Based on Asylum Support rates \\
\hline & Newcastle & $£ 100$ & \\
\hline
\end{tabular}

For the authorities who specified a weekly subsistence rate for families under section 17, it was not always clear what these rates were based on, and there were large variations in the amounts paid. However, a minority of local authorities did specify how their rates were calculated. Two used the equivalent rate that the family would receive if they were eligible for mainstream social security benefits, with one subtracting ten percent (for reasons that were not explained). Four mentioned asylum support rates as a starting point for calculating subsistence rates, and a further nine, although not mentioning asylum support, paid rates which appeared to be derived from Home Office asylum support rates.

Currently asylum support rates are $£ 37.75$ for each person in a household (or $£ 35.39$ in a voucher card for section 4 'hard case' support to refused asylum seekers). Additionally, pregnant mothers receive an additional $£ 3$ per week, and payments of $£ 5$ for a baby under 1 year old, and $£ 3$ for a child aged 1-3. This would equate to $£ 113.25$ per week, and fourteen of the 21 authorities who specified a rate paid less than this.

Using these rates, it is possible to calculate the amount of support for a notional household of one parent and two children of school age (see table 2). Despite the fact that many subsistence support rates appeared to mirror asylum support rates, there was also a tendency for subsistence rates to not be uprated to keep pace with increases in asylum support. Hence, over time these fell below the rates paid to asylum seekers. There was also confusion about their levels, particularly between the standard asylum support rate, and the lower, 'section 4' rate for refused asylum seekers. Some 
authorities offered extras such as a one-off winter clothes payment, payments for utility bills, and weekly additional payments to pregnant mothers, and pre-school children in line with asylum support. However, others paid less for subsequent children in the household after the first child.

This can also be compared with what the same family would receive if they were eligible for public funds. Working on the assumption of a family with no savings, in a Universal Credit area, a comparable family who were not subject to immigration control would be entitled to $f 225.14$ per week after housing costs, comprised of $£ 190.74$ from Universal Credit and child benefit of $£ 34.40$. A family would also be entitled to Local Housing Allowance (LHA) for housing costs, as well as free prescriptions, dental care, eye tests and free school meals for the children, and would be eligible for the NHS Low Income Scheme for help towards prescriptions for the parent. All but one authority who used a standard rate of subsistence support were paying less than the amount that the family could expect if they were eligible for mainstream social security benefits, and an average paid just 52 percent of the amount that the family would receive through mainstream social security.

\section{Discussion}

\section{Are subsistence rates sufficient to live on?}

Using the households below average income (HBAl) measure of relative poverty, the poverty line is currently $£ 306$ per week after housing costs for a family with one parent and two children aged 5 and 14 (DWP, 2018). Rates of subsistence support, were on average 61 percent below the poverty line (See table 2), with inner London boroughs paying the highest, and the non-London authorities paying the lowest. The majority of rates were lower than other mainstream social security or asylum support, and the lowest weekly amount of the surveyed local authorities corresponded to only $£ 3.10$ per day per household member, and the highest was $£ 10.72$ - all rates were below the HBAI poverty line.

An alternative indicator of deprivation is the Joseph Rowntree Foundation minimum income standard (Davis, et al. 2018). This measure is based on a consensus of the cost of everything which a household needs in order to 'achieve an acceptable living standard'. The standard is similar in intent and wording to the threshold for section 17 support under the Children Act of 'maintaining a reasonable standard of health or development'. Section 17 rates for families with NRPF were even further below the minimum income standard than the HBAI. In 2018, a household of one parent with two school age children would need $£ 412.35$ per week after housing costs and excluding the cost of council tax and childcare to achieve an acceptable living standard. However, the mean weekly rate of support across all authorities was 72 percent below the minimum income standard. Overall, authorities outside London were further below the poverty line than those in the capital, with inner London authorities having rates that were the closest to the poverty line and minimum income standards.

Table 2: Comparison of weekly payments to families with poverty lines

\begin{tabular}{|l|l|l|l|l|}
\hline & $\frac{\text { Inner London }}{\text { Mean }}$ & $\frac{\text { Outer London }}{\text { Mean }}$ & $\underline{\text { Regional mean }}$ & Total mean \\
\hline $\begin{array}{l}\text { Weekly section 17 payment for parent and 2 } \\
\text { children }\end{array}$ & $£ 133.56$ & $f 115.90$ & $f 106.18$ & $f 118.15$ \\
\hline Percentage below HBAl poverty line & $56 \%$ & $62 \%$ & $65 \%$ & $61 \%$ \\
\hline Percentage below minimum income standard & $68 \%$ & $72 \%$ & $74 \%$ & $71 \%$ \\
\hline
\end{tabular}




\section{Are support rates neglectful?}

In order to be indicative of statutory neglect, subsistence rates of support would have to first meet the criteria of neglect, and second to be a result of policy and/or legislation. Howarth's (2007) taxonomy of child neglect includes four types of neglect: physical, educational, emotional and medical. Educational neglect does not apply to children with NRPF as a matter of policy because schooling is not classed as a public fund in the immigration rules and so they are not excluded as a matter of policy. The restrictions on secondary medical care, and lack of access to prescription costs for children with NRPF could fall into the category of medical neglect, or as Howarth (2007) phrases it: "Failing to provide appropriate health care... and refusal of care". NHS healthcare is not the responsibility of local authorities, so is not relevant to section 17 support rates. However, physical neglect particularly resonates with the low support rates that families with NRPF are paid under section 17: 'failing to provide for a child's basic needs such as food, clothing or shelter' (Howarth, 2007, p.16-17). Certainly rates of support paid by local authorities around the country are far below the level of support reasonably expected by those who are not subject to immigration control. They are significantly lower than the equivalent rates of Universal Credit and Child Benefit that families with access to public funds would be paid. They are also consistently lower than the poverty line of 60 percent of median income and the JRF minimum income standards, and therefore would be unlikely to be high enough to consistently meet a child's "basic physical needs". Although it is beyond the scope of this chapter to assess the extent to which below poverty line support rates would be "likely to result in the serious impairment of the child's health or development", a parent or carer who consistently provided for some of the children in their care at a level that was knowingly below the minimum income for an adequate standard of living could reasonably meet the threshold for neglect.

The second criterion for statutory neglect is that it is as a result of policy/legislation rather than 'wilful ineptitude or negligence by a care service or individual'. Certainly there are examples of individual ineptitude and negligence in some cases (See for instance NELMA's accompanying work in London; Pinter, 2011). However, there is also evidence of positive attitudes and supportive relationships with social workers (Jolly, 2018). Nonetheless, the reason why families with NRPF approach local authorities for subsistence support and housing under section 17, rather than seeking employment or support through the mainstream social security system, is due to the NRPF policy itself. Most strikingly, the government's stated aim is to use immigration law and policy "to create here in Britain a really hostile environment" for those subject to immigration control, which suggests deliberate intent behind exclusionary policies towards families with NRPF (Kirkup and Winnet, 2012).

The welfare needs of families with NRPF are therefore neglected by the government in at least two ways: first, in the exclusionary policies themselves which remove the right to access welfare, and the lack of statutory guidance on meeting the needs of children with NRPF is itself a symptom of the way that the welfare needs of families with NRPF are neglected by the government. This results in a contradictory and ambivalent approach from local authorities (Thomas, Jolly and Goodson 2019). On the one hand, authorities have duties to safeguard child welfare and are often critical of the Home Office for leaving "families in limbo at a great emotional cost to them" (Lewisham, 2015). On the other hand, in the context of an austerity which has seen budgets cut, local authorities sometimes 
reduce the financial burden of support by paying below poverty line subsistence rates to families, or reducing the numbers of people who request support through aggressive 'gatekeeping' of services.

\section{The Local Authority Response}

In the absence of national guidance from government, some local authorities have responded with 'robust front door' gatekeeping. An approach which was pioneered by Lewisham Borough Council:

"It ...means establishing eligibility for NRPF in a robust and fair way. Without the intervention of this successful pilot we found that costs of NRPF may have increased to as much as $f 15,719,000$ by 2018. We support the robust front door approach that has been taken by the NRPF pilot project and recommend that the pilot approach is mainstreamed and made a permanent approach."

This approach entails restricting access to prevent families claiming support which they would be entitled to, and the impact of the policy can be seen in the fact that only 20 percent of families who were referred to Lewisham in the 2017/18 financial year received section 17 support. This was the lowest percentage of all local authorities, and compares with an average of 59 percent across all of the local authorities surveyed. This policy has been taken up by other local authorities across London - Lambeth Borough Council is on record as wanting to:

"drive down the cost of this service through a range of measures we are taking to narrow our front door and to expedite the closure of 'open cases' through a variety of means" (Lambeth, 2015)

Merton Borough Council have also taken on this 'robust' approach, coupling it with support to regularise families immigration status:

"We need to maintain a robust front door response and speed up the process of families lodging their applications and case management through the legal systems". (Merton, 2017)

Other local authorities did not appear to have a formal policy of gatekeeping to prevent families accessing support, but the large numbers of families with NRPF who were referred to children's services but did not receive section 17 support, and the testimony of advocacy organisations (such as NELMA, and Project 17) are perhaps indicative of similar processes at work on a more informal 'street level bureaucracy' basis.

\section{Why do local authorities respond in this way?}

Local authorities respond with this ambivalent approach towards families with NRPF for a number of reasons. First, in the context of austerity, Local Authorities have increasing budgetary constraints, while facing competing priorities for support. Children with no recourse to public funds are, by the admission of some local authorities themselves, not a priority compared to more 'desirable' groups. In evidence to the Clue judgment on support for families with NRPF, Birmingham City Council admitted that:

"The stark reality is that costs for people with no recourse to public funds is at the expense of other services the local authority is either required or expected to provide." (R. Clue v Birmingham 2010 EWCA Civ 460). 
Similarly, the Chair of the Public Accounts Select Committee for Lewisham Borough Council acknowledged that the vulnerability of children with NRPF had to be balanced against financial constraints:

"Due to their circumstances, children from such families are particularly vulnerable. However, there is no government grant available to authorities for their support and no provision within the Council's base budget. The need to balance these issues is a considerable challenge." (Lewisham 2015)

Second, the costs to local authorities of supporting families with NRPF are increasing. The best estimates are that the numbers of undocumented migrant families are growing (Dexter, Capron, and Gregg, 2016; Jolly, Thomas and Stanyer, 2019), and consequently more families are approaching local authorities for support. In one particularly striking example, Lewisham Council's Overview and scrutiny report on the cost of NRPF support found that in 2008 the annual cost of support for families with NRPF was $£ 242,000$. But by 2012 the costs had increased to $£ 2,244,000$ and by 2013 had increased again to $£ 5,368,000$ (Lewisham, 2015).

Third, Home Office decisions such as granting people discretionary leave to remain in the UK without recourse to public funds (Guentner et al, 2016), and the continuing 'backlogs' of immigration applications, increase costs to local authorities considerably by passing costs which wold be met by the national social security system onto local government. Again, Lewisham Borough Council (2015) were particularly blunt about where they considered that the blame lay for the rising costs of supporting families with NRPF:

"The conclusions of this committee were clear; that Home Office incompetence directly contributes to council overspends."

"In addition, we hope [this scrutiny report] will go some way to informing the public as to the vast sums councils are forced to spend to cover up Home Office chaos. It cannot be right that the never-ending saga of Home Office disarray drags local councils down with it and if I were permitted to make one personal recommendation it would be that the Home Secretary make an urgent statement as to her plans for remedying this latest costly failure."

\section{Conclusions}

Despite often being from the same Commonwealth countries as the Windrush generation, migrants from the Air Jamaica generation have featured less in policy discussions about the impact of the hostile environment, or in conversations about the impact of austerity and welfare conditionality on levels of poverty in the UK. Without the entitlement to access mainstream welfare services, families can experience destitution, and are often reliant on section 17 support from local authority children's services. In the absence of guidance to local authority children's services on section 17 support for families with NRPF, a parallel, ad hoc benefits system has developed which is independent of mainstream social security and all but invisible in the social policy literature. While this system goes further than other forms of welfare conditionality, it resonates with other trends in welfare and social security towards a more informal, discretionary, localised welfare system. 
Analysis of subsistence support indicates that rates are too low to lift children out of poverty, or to achieve the section 17 aim of maintaining a 'reasonable standard of health or development'. Rates of subsistence support that are paid to families vary widely by local authority, but are consistently below the amount needed to maintain an adequate standard of living as measured by the equivalent social security benefit entitlement, the HBAI poverty line or the minimum income standard.

It is reasonable to conclude therefore that, based on the definition of child neglect in England, a parent or care giver who consistently provided a standard of support for some of the children in their care which was less than adequate for a reasonable standard of living would be viewed as neglectful. Furthermore, as the reason that families are approaching local authorities for section 17 support is the NRPF restrictions on mainstream social security, the neglect is statutory in nature.

Although this parallel system is a result of national policies of welfare conditionality such as the NRPF rule, it is administered and enforced at a local authority level through bordering practices such as 'robust front door' policies. These policies employ gatekeeping to prevent access to subsistence support, and undermine both the Children Act principle of the welfare of the child being paramount, and the social work values of 'empowerment and liberation of people' (IFSW, 2014). Local authorities are in a conflicted position of having safeguarding duties towards children irrespective of immigration status, but without the resources to do so in a context of austerity and a hostile environment towards people who are subject to immigration control.

\section{References}

Arnorsson, A. \& Zoega, G., 2018. On the causes of Brexit. European Journal of Political Economy. Available at: http://dx.doi.org/10.1016/j.ejpoleco.2018.02.001.

Barn, R. and Kirton, D., 2014. CHILD WELFARE AND MIGRANT FAMILIES AND CHILDREN. Child Welfare Systems and Migrant Children: A Cross Country Study of Policies and Practice

Birmingham City Council v Clue [2010] EWCA Civ 460

Department for Education, 2018. What is a suitable placement for an unaccompanied asylum seeking child? - Information for local authorities to accompany the national transfer protocol for unaccompanied asylum seeking children. London

https://www.local.gov.uk/sites/default/files/documents/Suitable\%20placements\%20for\%20UASC\% 20updated\%20April\%202018\%20Final.pdf

Corby, B., Shemmings, D., \& Wilkins, D. (2012). Child abuse: An evidence base for confident practice (4th ed.). Maidenhead: Open University Press

Davis, A., Hirsch, D., Padley, M. and Shepherd, C., 2018. A Minimum Income Standard for the UK 2008-2018: continuity and change. York: JRF

Department for Education (2018a) What is a suitable placement for an unaccompanied asylum seeking child? Information for local authorities to accompany the national transfer protocol for unaccompanied asylum seeking children. London: The Stationery Office 
Department for Education (2018). Working together to safeguard children: Statutory guidance on inter-agency working to safeguard and promote the welfare of children. London: The Stationery Office.

Dexter, Z., Capron, L. and Gregg, L., 2016. Making Life Impossible: How the needs of destitute migrant children are going unmet. London: The Children's Society

Dickson, E. (2019) Not Seen, Not Heard: Children's experiences of the hostile environment. London: Project 17 https://www.project17.org.uk/policy/campaigns/seen-and-heard/

Dowler, E. and Lambie-Mumford, H., 2015. How can households eat in austerity? Challenges for social policy in the UK. Social Policy and Society, 14(3), pp.417-428.

Dudley, Rebecca (2014?) Domestic Abuse and Women with No Recourse to Public Funds: Where Human Rights Do Not Reach. Belfast: Belfast Area Domestic \& Sexual Violence and Abuse Partnership

DWP, 2018, Households Below Average Income, 1994/95 to 2016/17 Table 2.4ts: Equivalent money values of overall distribution mean, median, and 60 per cent of median income for different family types in 2016/17 prices, United Kingdom https://www.gov.uk/government/statistics/hbai-199495to-201617-incomes-data-tables

Dwyer, P., 2004. Creeping Conditionality in the UK: From Welfare Rights to Conditional Entitlements? The Canadian Journal of Sociology, 29(2), pp.265-287. Available at:

http://dx.doi.org/10.1353/cjs.2004.0022.

Dwyer, P. and Wright, S., 2014. Universal credit, ubiquitous conditionality and its implications for social citizenship. The Journal of Poverty and Social Justice, 22(1), p.27.

Erikson, M., \& Egeland, B. (2002). Child neglect. In J. B. Klika \& J. R. Conte (Eds.), The ASPSAC handbook on child maltreatment (pp. 3-20). Thousand Oaks, CA: Sage.

Farmer, N.J., 2017. 'No Recourse to Public Funds', insecure immigration status and destitution: the role of social work? Critical and Radical Social Work, 5(3), pp.357-367.

Garthwaite, K., 2016. Hunger pains: Life inside foodbank Britain. Bristol: Policy Press.

Goodwin, M. and Milazzo, C. (2017) 'Taking back control? Investigating the role of immigration in the 2016 vote for Brexit', The British Journal of Politics and International Relations, 19(3), pp. 450-464. doi: $10.1177 / 1369148117710799$

Gietel-Basten, S., 2016. Why Brexit? The Toxic Mix of Immigration and Austerity. Population and Development Review, 42(4), pp.673-680. Available at: http://dx.doi.org/10.1111/padr.12007.

Guentner, S., Lukes, S., Stanton, R., Vollmer, B.A. and Wilding, J., 2016. Bordering practices in the UK welfare system. Critical Social Policy, 36(3), pp.391-411.

HM Government. (2015). Working together to safeguard children: A guide to inter-agency working to safeguard and promote the welfare of children. HM Government. Retrieved from www.gov.uk/government/ publications/working-together-to-safeguard-children -2 
Horwath, J. (2007) Child neglect: identification and assessment. Basingstoke: Palgrave Macmillan.

Humphries, B., 2004. An unacceptable role for social work: Implementing immigration policy. British Journal of Social Work, 34(1), pp.93-107.

IFSW (2014) Global Definition of the Social Work Profession https://www.ifsw.org/what-is-socialwork/global-definition-of-social-work/

Independent (2015) Over 50,000 families shipped out of London boroughs in the past three years due to welfare cuts and soaring rents The Independent Wednesday 29 April 2015

https://www.independent.co.uk/news/uk/home-news/over-50000-families-shipped-out-of-londonin-the-past-three-years-due-to-welfare-cuts-and-soaring-10213854.html

Jolly, A. (2018). No Recourse to Social Work? Statutory Neglect, Social Exclusion and Undocumented Migrant Families in the UK. Social Inclusion, 6(3), 190-200.

doi:http://dx.doi.org/10.17645/si.v6i3.1486

Jolly, A. Thomas, S and Stanyer, J. (2019) London's children and young people who are not British citizens: A profile. Wolverhampton: Institute for Community Research and Development / Greater London Authority

Kirkup, J., and Winnet, R., 2012, "Theresa May interview: 'We're going to give illegal migrants a really hostile reception" The Daily Telegraph $25^{\text {th }}$ May 2012

https://www.telegraph.co.uk/news/uknews/immigration/9291483/Theresa-May-interview-Weregoing-to-give-illegal-migrants-a-really-hostile-reception.html

Lambeth Borough Council, 2015, Cabinet Member Delegated Decision: Increase in Subsistence Payments Paid to Families with No Recourse to Public Funds

https://moderngov.lambeth.gov.uk/documents/s72437/Final uplifting\%20NRPF\%20subsistence\%20 rates\%20docx\%2019\%2002.pdf

Lambie-Mumford, H. \& Dowler, E., 2014. Rising use of "food aid" in the United Kingdom P. Martin Caraher and Dr Alessio Cavic, ed. British Food Journal, 116(9), pp.1418-1425. Available at:

http://dx.doi.org/10.1108/BFJ-06-2014-0207.

Lewisham Borough Council, 2015, Overview and Scrutiny, No Recourse to Public Funds Review, Public Accounts Select Committee

http://councilmeetings.lewisham.gov.uk/documents/s33873/No\%20Recourse\%20to\%20Public\%20F unds\%20Review.pdf

Loopstra Rachel, Reeves Aaron, Taylor-Robinson David, Barr Ben, McKee Martin, Stuckler David Austerity, sanctions, and the rise of food banks in the UK BMJ 2015; 350 :h1775

Mackenzie, D. and Stephens, A. (2015) Research into how 'No Recourse to Public Funds' status affects those experiencing gender based violence, domestic abuse and sexual violence in Wales Cardiff: Local Government Data Unit

http://www.wsmp.org.uk/documents/wsmp/No\%20Recourse\%20to\%20Public\%20Funds/No\%20Rec ourse\%20to\%20Public\%20Funds\%20Research\%20report\%202015\%20FINAL\%20v4.pdf 
Merton Borough Council, 2017, Financial Monitoring Task Group (FMTG), Briefings on UASC, NRPF, SIA expenditure and key issues

https://democracy.merton.gov.uk/documents/s16472/CSF\%20deepdive\%2020.02.17.pdf

Merton Borough Council (2018) Freedom of Information Act 2000 / Environmental Information Regulations 2004 Information request $27^{\text {th }}$ September 2018, Information Governance Team, London: Merton Borough Council

NELMA (n.d.) Our Manifesto https://nelmacampaigns.wordpress.com/nelma-manifesto/

NRPF Network (2018) Practice Guidance: Assessing and supporting children and families with NRPF London: Islington Borough Council http://guidance.nrpfnetwork.org.uk/reader/practice-guidancefamilies/

NSPCC (2018) National Case Review Repository https://learning.nspcc.org.uk/case-reviews/nationalcase-review-repository/

OHCHR (2018) Statement on Visit to the United Kingdom, by Professor Philip Alston, United Nations Special Rapporteur on extreme poverty and human rights

https://www.ohchr.org/Documents/Issues/Poverty/EOM GB 16Nov2018.pdf

Section 7, Local Authority Social Services Act 1970

http://www.legislation.gov.uk/ukpga/1970/42/section/7

Smith, F. (2018) Serious Case review "Ellie": Overview Report Chatham: Medway LSCB,

Pinter, I., 2011. 'I Don't Feel Human': Experiences of Destitution Among Young Refugees and Migrants. London: Children's Society.

Price, J. and Spencer, S., 2015. Safeguarding children from destitution: Local authority responses to families with 'no recourse to public funds'. Oxford: COMPAS

www.compas.ox.ac.uk/fileadmin/files/Publications/Reports/PR-

2015No Recourse Public Funds LAs.Pdf

Redbridge Borough Council (2018) Freedom of Information Act 2000 request Ref. 3449840 11th

October 2018, Children's Services team, London: Redbridge Borough Council

Reeve, K., 2017. Welfare conditionality, benefit sanctions and homelessness in the UK: ending the "something for nothing culture" or punishing the poor? Journal of Poverty and Social Justice, 25(1), pp.65-78. Available at: http://dx.doi.org/10.1332/175982717X14842281240539

Sethi, D., Bellis, M., Hughes, K., Gilbert, R., Mitis, F., \& Galea, G. (2013). European report on preventing child maltreatment. Geneva: World Health Organisation.

Shutes, Isabel (2017) Controlling migration: the gender implications of work-related conditions in restricting rights to residence and social benefits. In: Hudson, John and Needham, Catherine and Heins, Elke, (eds.) Social policy review 29: Analysis and debate in social policy, 2017. Policy Press, Bristol, UK. 
Taylor-Gooby, Peter (2016) The Divisive Welfare State. Social Policy and Administration, 50 (6). pp. 712-733.

Thomas, S. Jolly, A. and Goodson, L. (2019) Undocumented children in London and their heath and wellbeing. Birmingham: University of Birmingham / Barnardo's

US Department of Health and Human Services. (2010). The child abuse prevention and treatment Act 2010: Including adoption opportunities \& the abandoned infants assistance Act (CAPTA P.L. 111-320 Booklet). Washington, DC: US Department of Health and Human Services. Retrieved from www. acf.hhs.gov/cb/resource/capta2010

Wimmer, A. and Glick Schiller, N., 2002. Methodological nationalism and beyond: nation-state building, migration and the social sciences. Global networks, 2(4), pp.301-334. 